\title{
Nanoporous Aluminosilicate-Catalyzed Telescoped Acetalization- Direct Aldol Reactions of Acetals with 1,3-Dicarbonyl Compounds
}

\author{
Thomas Edward Davies, ${ }^{\dagger}$ Stuart Hamilton Taylor, ${ }^{\dagger}{ }^{\dagger}$ and Andrew Edward Graham* ${ }^{*} \ddagger$ \\ ${ }^{\dagger}$ Cardiff Catalysis Institute, School of Chemistry, Cardiff University, Main Building, Park Place, Cardiff CF10 3AT, U.K. \\ ${ }^{\star}$ School of Applied Sciences, University of South Wales, Pontypridd CF37 4AT, U.K.
}

\section{Supporting Information}

ABSTRACT: Nanoporous aluminosilicate materials, synthesized by an evaporation-induced self-assembly process, catalyze the direct aldol reaction of acyclic acetals with a range of 1,3-dicarbonyl compounds to produce the corresponding aldol addition products in high yield, rather than the expected Knoevenagel elimination products. By carrying out the reaction in the presence of either dimethoxy propane or the corresponding orthoester, it is possible to capitalize on the ability of these aluminosilicate materials to catalyze the corresponding acetalization reaction leading to the development of novel telescoped, acetalization-direct aldol addition reaction protocols.

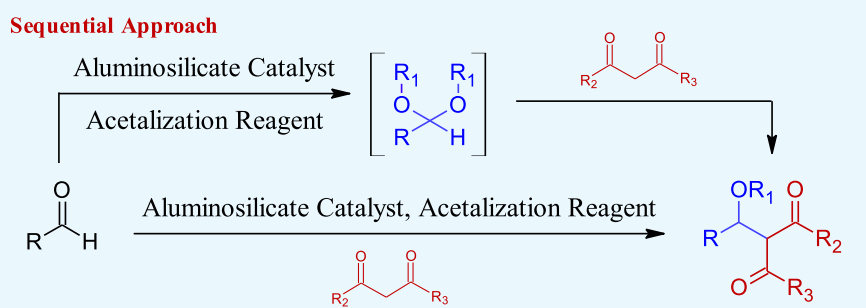

Tandem Approach

\section{INTRODUCTION}

The ongoing interest in the formation of carbon-carbon bonds by the addition of activated methylene compounds to electrophilic centers, and in particular the development of asymmetric variants, bears testament to the flexibility and generality of this approach as a synthetic strategy. ${ }^{1-3}$ The aldol reaction in particular has found widespread use in the synthesis of a range of natural products and pharmaceutical components, and its importance is reflected in the number of new developments in this area, which have greatly extended its scope. ${ }^{4,5}$ These innovations include organocatalytic asymmetric variants, ${ }^{6}$ protocols employing novel acidic and basic catalysts under heterogeneous conditions, ${ }^{7-9}$ and protocols with a reduced environmental impact. ${ }^{10-12}$ One significant limitation in the scope of the aldol reaction to date has been in reactions employing readily enolizable 1,3-dicarbonyl compounds, such as 1,3-diketones, 1,3-ketoesters, and malonates. The development of synthetically useful routes to access $\beta$ hydroxycarbonyl compounds derived from these activated carbonyl compounds is of particular interest as they have been identified as useful intermediates in natural product synthesis. ${ }^{13-15}$ Additionally, 3-substituted-2,4-pentanedionates have been identified as useful chelating motifs in functionalized materials displaying novel photochemical properties. ${ }^{16}$ Typical aldol reaction conditions, employing basic conditions, generate chelated enolate intermediates, which are unreactive, and when successful, the $\beta$-hydroxycarbonyl products generated are prone to undergo facile elimination reactions to produce Knovenagel products or retro-aldol reaction to regenerate starting materials. ${ }^{17,18}$ Currently, only a comparatively small number of synthetic strategies has addressed this limitation, exploiting multicomponent processes, which trap the unstable $\beta$-hydroxycarbonyl intermediates to limit the retro-aldol reaction or use very mild reaction conditions employing very weak acids or bases. ${ }^{18,19}$ The lack of suitable aldol protocols has led to the development of alternative synthetic strategies to access $\beta$-hydroxycarbonyl products, such as the oxy-Michael addition reaction of alkoxide nucleophiles under strongly basic conditions. $^{20}$

Our interest in this area was prompted by the observation that acyclic acetals undergo direct aldol reactions with activated methylene compounds in the presence of strong Lewis acids at very low reaction temperatures to give the corresponding addition products (Scheme 1$).^{21}$ The reaction of carbonyl derivatives, such as acetals and acylals, as surrogates for carbonyl compounds is a surprisingly mature area $^{22,23}$ and is a useful strategy for carbon-carbon bond formation albeit one that has been comparatively under exploited. ${ }^{24-29}$

We have previously demonstrated that our nanoporous aluminosilicate materials are relatively ineffective in catalyzing addition reactions to carbonyl substrates, but are highly efficient in catalyzing the corresponding reactions with acetal substrates. ${ }^{30}$ Presumably, these reactions are proceeding through a highly reactive oxocarbenium ion intermediate that rapidly undergoes subsequent reaction with the nucleophilic species. ${ }^{31-34}$ If a similar reactivity pattern was in operation with activated carbonyl compounds, the addition products generated would be resistant to retro-aldol and so would provide access to an effective strategy to address problematic aldol reactions. Herein, we report the successful development of the direct aldol reactions of 1,3-dicarbonyl compounds to

Received: August 15, 2018

Accepted: November 1, 2018

Published: November 14, 2018 
Scheme 1. Direct Aldol Reaction of Acetals with 1,3-Dicarbonyl Compounds

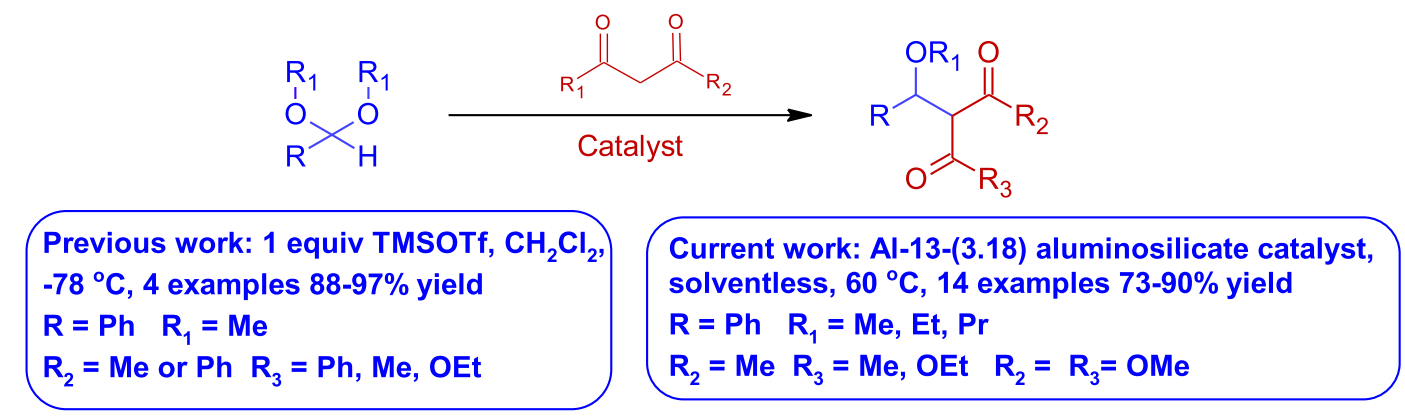

Table 1. Catalyst Screening Studies ${ }^{a}$

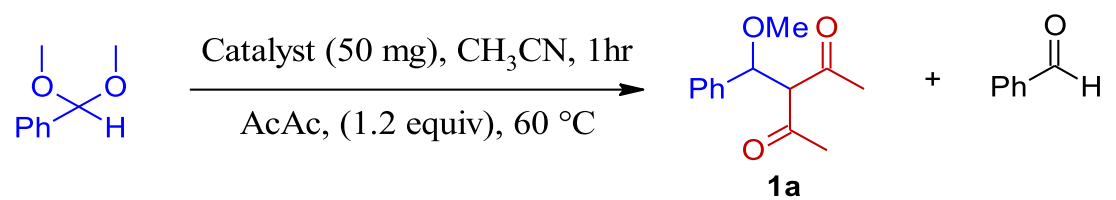

\begin{tabular}{clccc}
\hline entry & \multicolumn{1}{c}{ catalyst $^{b}$} & selectivity $^{c}$ & \left.${\text { conversion }(\%)^{d}}^{\text {conversion to 1a (\%) }}\right)^{d, e}$ \\
1 & Al-13-(2.34) & $2.5: 1$ & 95 & 67 \\
2 & Al-56-(1.87) & $2.3: 1$ & 84 & 58 \\
3 & Al-13-(3.18) & $3: 1$ & 93 & 70 \\
4 & Al-54-(3.06) & $2: 1$ & 79 & 52 \\
5 & B-13-(3.54) & & $<10$ & $<10$ \\
6 & S-1-(3.42) & $1: 1$ & $<10$ & $<10$ \\
7 & ZSM-5-30-(0.82) & $1.3: 1$ & 42 & 21 \\
8 & zeolite Y5-(1.11) & & 64 & 36 \\
9 & 3 Å MS & & $<10$ & 0 \\
10 & & & $<5$ & 0 \\
11 & Al-13-(3.18) & & 0 & $0^{f}$
\end{tabular}

${ }^{a}$ Experimental conditions: the catalyst $(50 \mathrm{mg})$ was added to a solution of BDMA $(1 \mathrm{mmol})$ and AcAc $(1.2 \mathrm{mmol})$ in acetonitrile $(3 \mathrm{~mL})$ in a sealed reaction vessel and heated to $60^{\circ} \mathrm{C}$ with vigorous stirring. ${ }^{b}$ Catalyst notation: silica/metal ratios are given in parentheses; catalyst pore sizes are given in brackets. ${ }^{c}$ Ratio of 1 a to benzaldehyde. ${ }^{d}$ Determined by ${ }^{1} \mathrm{H}$ NMR spectroscopy on the crude reaction mixture. ${ }^{e}$ Reactions contain $<2 \%$ Knoevenagel products. ${ }^{f}$ Reaction employing benzaldehyde.

acyclic aromatic acetals employing an easily accessible and recyclable heterogeneous aluminosilicate catalyst and the subsequent development of telescoped acetalization-aldol addition procedures.

\section{RESULTS AND DISCUSSION}

We initially assessed the ability of a range of our heterogeneous silicate materials, produced using a simple evaporation-induced self-assembly (EISA) approach, ${ }^{30,35-39}$ displaying different pore sizes and acidities (see Table $S 1$ for catalyst properties), to catalyze the addition of acetyl acetone (AcAc) to benzaldehyde dimethyl acetal (BDMA). For comparative purposes, a selection of readily available commercial aluminosilicate zeolite catalysts was also investigated. We were highly gratified to observe that both our high- and lowaluminum nanoporous silicate materials effectively catalyzed the direct aldol addition reaction to give good conversions to the addition product 1a, which was independent of the catalyst pore size (Table 1, entries $1-4) .{ }^{1} \mathrm{H}$ NMR analysis also confirmed the presence of varying quantities of benzaldehyde, produced by hydrolysis of BDMA, in these crude reaction mixtures.

Importantly, and in contrast to previous literature reports employing zeolites, acidic clays, aluminosilicates, or metalorganic framework materials, only trace quantities of the Knovenagel product were observed in these crude reaction mixtures. ${ }^{40-43}$ Presumably, the comparatively mild reaction conditions and short reaction times employed, in addition to the moderate acidity of the aluminosilicate catalysts, are sufficient to catalyze the direct aldol addition reaction, but not acidic to catalyze the corresponding elimination reaction. Indeed, the subsequent addition of a stronger acidic reagent, such as Amberlyst-15, to a crude sample of 1a under our standard reaction conditions led to complete conversion to the expected Knovenagel elimination product. Furthermore, ${ }^{1} \mathrm{H}$ NMR and gas chromatography-mass spectrometry (GC-MS) analyses of the crude reaction mixtures indicated that no products derived from the addition of AcAc to acetonitrile were produced. ${ }^{44,45}$ The highly Lewis acidic borosilicate material (B-13-(3.54)) gave little of the desired addition product, as did the plain silicate material (S-1) (entries 5 and $6)$, and starting materials were recovered largely unchanged. The commercially available zeolites ZSM-5-(30), zeolite Y5, and $3 \AA$ molecular sieves also proved to be largely ineffective, giving only limited quantities of the addition product 1a (entries 7-9). Importantly, repeating the reaction in the absence of the aluminosilicate catalyst (entry 10), or with benzaldehyde in place of BDMA (entry 11), resulted in no aldol addition products being generated, highlighting the significant difference in reactivity of the acetal compared to the corresponding aldehyde under aluminosilicate catalysis. 
Table 2. Optimization of the Direct Aldol Addition Reaction of Acetyl Acetone with BDMA ${ }^{a}$

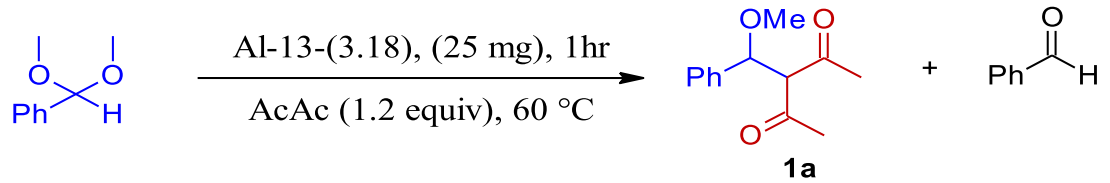

\begin{tabular}{clccc}
\hline entry & solvent & selectivity ${ }^{b}$ & conversion $(\%)^{c, d}$ & conversion to 1a (\%) $^{c}$ \\
1 & $\mathrm{CH}_{3} \mathrm{CN}$ & $3: 1$ & 93 & 70 \\
2 & $\mathrm{CHCl}_{3}$ & $1.5: 1$ & 78 & 47 \\
3 & $\mathrm{MeOH}$ & $>10$ & $>10$ \\
4 & hexane & $2: 1$ & 65 & 43 \\
5 & $\mathrm{DMC}$ & $3: 1$ & 83 & 62 \\
6 & & $4: 1$ & 98 & 78 \\
7 & & $19: 1$ & 90 & $86^{e}$ \\
8 & & $17: 1$ & 85 & $80^{f}$ \\
9 & $20: 1$ & 89 & $88^{f, g}$
\end{tabular}

${ }^{a}$ Experimental conditions: the catalyst $(25 \mathrm{mg})$ was added to a solution of BDMA $(0.5 \mathrm{mmol})$ and AcAc $(0.6 \mathrm{mmol})$ in the specified solvent $(3$ $\mathrm{mL}$ ) in a sealed reaction vessel and heated to $60{ }^{\circ} \mathrm{C}$ with vigorous stirring. Reactions under solvent-free conditions employ 5 equiv of AcAc. ${ }^{b}$ Ratio of 1 a to benzaldehyde. ${ }^{c}$ Determined by ${ }^{1} \mathrm{H}$ NMR spectroscopy on the crude reaction mixture. ${ }^{d}$ Reactions contain $<2 \%$ Knoevenagel products. ${ }^{e} 0.5$ equiv of trimethyl orthoformate (TMOF) was added after $30 \mathrm{~min}$ and the reaction heated for an additional 30 min. ${ }^{f_{0.5}}$ equiv of dimethoxy propane (DMOP) was added after $30 \mathrm{~min}$ and the reaction heated for an additional $30 \mathrm{~min} .{ }^{g}$ Reaction using recycled catalyst.

Table 3. Scope of the Direct Aldol Addition of 1,3-Dicarbonyl Compounds to Acyclic Acetals

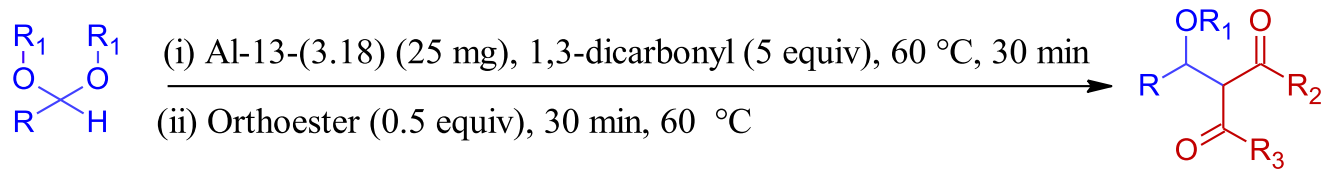<smiles>CCC(OC)C(C(C)=O)C(C)=O</smiles>

1a $85 \%^{\mathrm{a}}$<smiles>CCOC(C(C)=O)C(C(C)=O)c1ccc(C)cc1</smiles>

1 e $78 \%$<smiles>CCOC(c1ccc(Br)cc1)C(C(C)=O)C(C)=O</smiles><smiles>CCOC(=O)C(C(=O)OC)C(OC)c1ccccc1</smiles><smiles>CCOC(C(C)=O)C(C(C)=O)c1ccccc1</smiles>

1 b $86 \%$<smiles>COc1ccc(C(OC)C(C(C)=O)C(C)=O)cc1</smiles>

1f $75 \%$<smiles>CCOC(c1ccc([N+](=O)[O-])cc1)C(C(C)=O)C(C)=O</smiles>

1j $80 \%$<smiles>CCOC(C(=O)OC)C(C(=O)OC)c1ccc(C)cc1</smiles>

3b $85 \%$ e,f<smiles>CCCC(C(C)=O)C(C(C)=O)c1ccccc1</smiles>

1c $83 \%{ }^{\mathrm{b}}$<smiles>CCOC(c1ccc(OC)cc1)C(C(C)=O)C(C)=O</smiles>

$\lg 73 \%$<smiles>CCOC(=O)C(C(C)=O)C(OC)c1ccccc1</smiles><smiles>COC(c1ccc(C)cc1)C(C(C)=O)C(C)=O</smiles>

1d $85 \%{ }^{\mathrm{a}}$

Me

1h $80 \%{ }^{b}$<smiles>CCOC(=O)C(C(C)=O)C(C(=O)O[Na])c1ccccc1</smiles>

${ }^{a}$ Reaction employs 0.5 equiv DMOP. ${ }^{b}$ No additional orthoester step was required. ${ }^{c}$ Isolated as an approximate $1: 1$ mixture of diastereoisomers. ${ }^{\mathrm{d}}$ Recycled catalyst. ${ }^{\mathrm{e}}$ Reaction at $50{ }^{\circ} \mathrm{C}$ for 90 minutes. ${ }^{\mathrm{f}}$ Product contains $\sim 5 \%$ Knoevenagel product.

${ }^{a}$ Reaction employs 0.5 equiv DMOP. ${ }^{b}$ No additional orthoester step was required. ${ }^{c}$ Isolated as an approximate 1:1 mixture of diastereoisomers. ${ }^{d}$ Recycled catalyst. ${ }^{e}$ Reaction at $50{ }^{\circ} \mathrm{C}$ for $90 \mathrm{~min} .{ }^{f}$ Product contains $\sim 5 \%$ Knoevenagel product.

We next undertook studies to further optimize the addition reaction employing our high aluminum containing, large-pore aluminosilicate material Al-13-(3.18) as catalyst (Table 2). Examination of a range of alternative solvents generally proved 
Scheme 2. Telescoped Reactions of Aldehydes with 1,3-Dicarbonyl Compounds

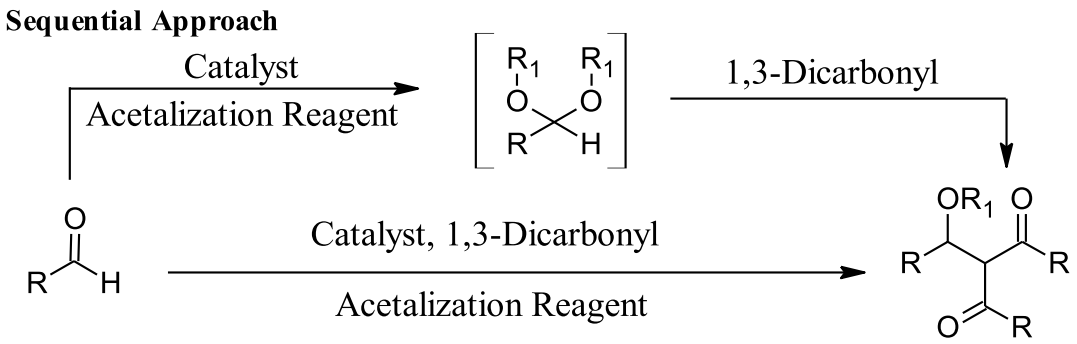

Tandem Approach

detrimental to the overall reaction outcome (entries 1-4), with only dimethyl carbonate (DMC) providing comparable results to acetonitrile (entry 5). Interestingly, carrying out the reaction under solvent-free reaction conditions employing an excess of AcAc provided a high conversion to 1a with reduced acetal hydrolysis (entry 6). We recognized that further improvements in both selectivity and overall yield of $\mathbf{1 a}$ could be achieved if the quantities of benzaldehyde, generated by the competing hydrolysis of BDMA, could be reduced. Our strategy in this case, rather than attempting the difficult and tedious task of ensuring strictly anhydrous conditions, is to capitalize on the proven ability of the aluminosilicate material to catalyze the acetalization reaction and simply regenerate the acetal in situ. ${ }^{36,39,46,47}$ An additional benefit of these optimization studies is that it sets the scene for subsequent studies directed toward the development of telescoped protocols, which further exploit the selectivity displayed by these catalysts for the aldol addition reaction with acetal substrates over the corresponding carbonyl substrates.

Our initial studies in this area proved encouraging. The addition of trimethyl orthoformate (TMOF) significantly reduced the quantity of benzaldehyde in the crude reaction mixture, with a subsequent increase in the quantity of BDMA, although conversions to 1a displayed only moderate improvements even after extended reaction times. Since catalyst deactivation is unlikely given the successful acetalization reaction, we reasoned that the methanol generated during hydrolysis and acetalization reactions might be sufficient to shift the tautomeric ratio of AcAc toward its unreactive keto form. ${ }^{48}$ To address this potential limitation, and to ensure greater consistency and reproducibility, methanol in the crude reaction mixture was removed on completion of the initial aldol addition reaction using a gentle stream of nitrogen gas prior to the addition of the TMOF. Under these modified reaction conditions, significant improvements in the formation of 1a were achieved employing either TMOF (entry 7) or dimethoxy propane (DMOP) (entry 8 ). In reactions employing these additional quantities of TMOF, ${ }^{1} \mathrm{H}$ NMR and GCMS analyses indicated that no products derived from the addition of AcAc to TMOF were produced, ${ }^{49}$ and only trace quantities of 4-methoxy-3-penten-2-one were detected in the crude reaction mixtures. ${ }^{50}$ In the case of reactions employing DMOP, no aldol addition products to either DMOP or acetone were observed. In line with our previous studies, the nanoporous material could also be isolated from the reaction mixtures and reused either directly or after a short recalcination step without loss of catalytic activity (entry 9). ${ }^{36,37}$
With the reaction conditions optimized, we examined the scope of the reaction employing a range of acyclic aromatic acetals and 1,3-dicarbonyl compounds (Table 3).

In cases where acetal hydrolysis exceeded $\sim 20 \%$ in the initial aldol reaction, an additional quantity of the corresponding orthoester was included in the reaction protocol, although in a number of cases, the starting acetals proved sufficiently stable to hydrolysis, and the additional reacetalization step was deemed not to be necessary. The aldol addition reaction proved to be tolerant of a range of acylic aromatic acetals employing either AcAc $(\mathbf{1} \mathbf{a}-\mathbf{1 j})$, ethyl acetoacetate $(\mathbf{2} \mathbf{a}-\mathbf{3 b})$, or dimethyl malonate ( $\mathbf{3} \mathbf{a}$ and $\mathbf{3} \mathbf{b}$ ), giving the addition products in high yield and in short reaction times. The addition products $3 \mathbf{a}$ and $\mathbf{3 b}$ derived from dimethyl malonate proved to be unstable at $60{ }^{\circ} \mathrm{C}$ and in these cases the reaction was conducted at $50{ }^{\circ} \mathrm{C}$ with a short extension of the reaction time. In contrast to the reactions employing AcAc, trace quantities of products derived from addition of ethyl acetoacetate and dimethyl malonate to the orthoformate were observed in the crude reaction mixtures.

We next studied the scope of the addition reaction with an extended range of acetal substrates. No significant reaction was observed with cyclic acetals, presumably due to the increased stability of these substrates, ${ }^{28}$ and only starting material was obtained in the reaction of 2-phenyl-1,3-dioxane with AcAc. In line with previous literature reports, the reaction of simple acetals derived from alkyl acetals, such as valderaldehyde diethyl acetal, provided only small quantities of the desired addition product on reaction with AcAc. The reduced reactivity observed in this case is due to the decrease in the stability of the reactive oxocarbenium intermediate generated from the acetal starting material. ${ }^{17}$ Similarly, ketals, such as acetophenone dimethyl acetal, were unreactive under the reaction conditions employed due to steric limitations and gave no identifiable aldol addition products. ${ }^{21}$ Overall, this methodology provides an operationally simple and effective method to access $\beta$-alkoxycarbonyl products by a direct aldol approach and provides a useful alternative strategy to existing oxa-Michael protocols. ${ }^{51}$

Finally, we addressed the possibility of developing telescoped reaction protocols, in which the acetal substrate is generated in situ from the corresponding aldehyde and an acetalization reagent in the presence of the catalyst, followed by subsequent direct aldol reaction with a 1,3-dicarbonyl compound. There has been significant recent interest in the development of reaction sequences where multiple synthetic transformations are achieved without the isolation and purification of intermediates, as they offer considerable improvements in both efficiency and the overall atom efficiency. ${ }^{52-54}$ We considered two strategies to achieve this 
Table 4. Scope of the Telescoped Acetalization-Direct Aldol Addition of 1,3-Dicarbonyl Compounds

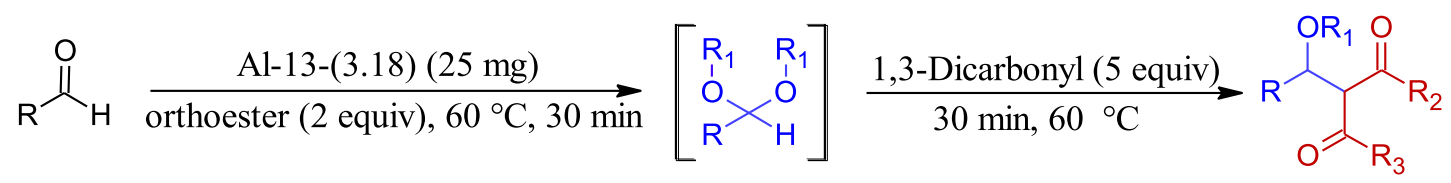

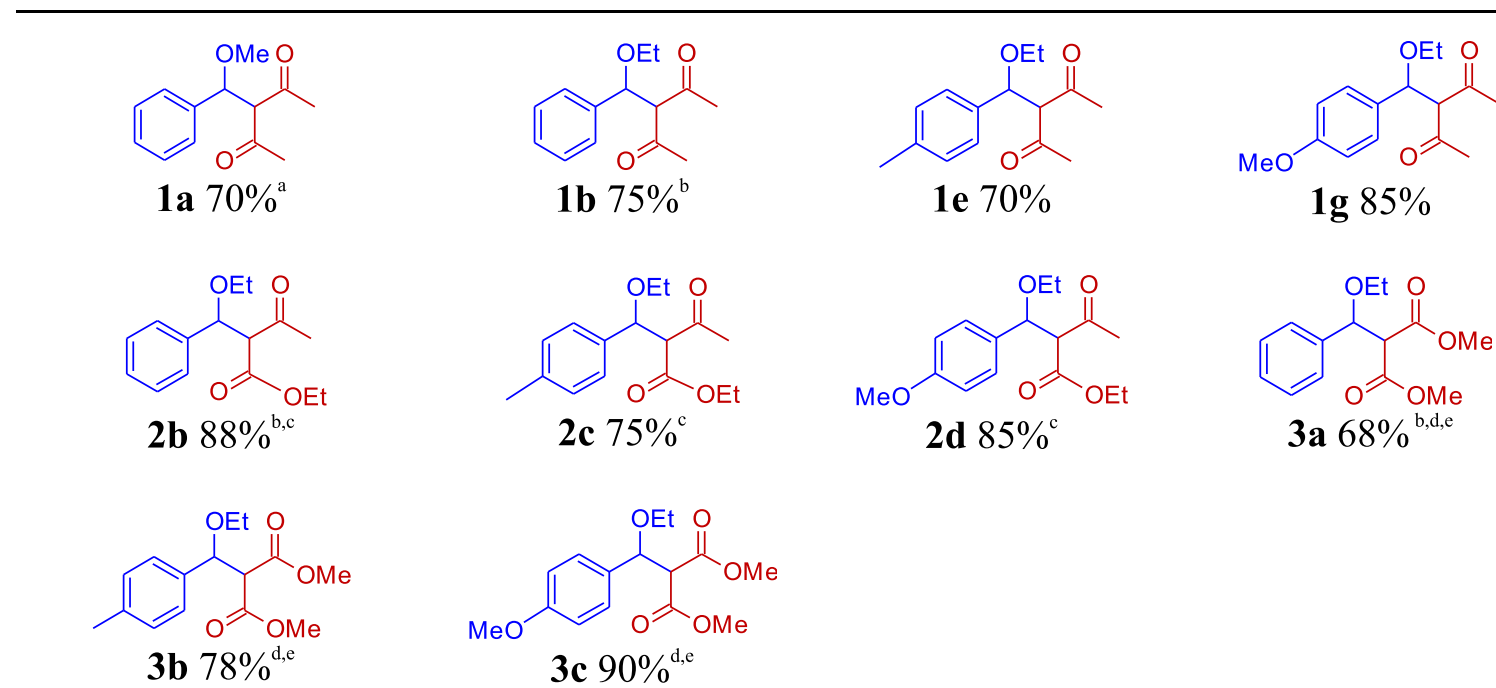

${ }^{\mathrm{a}}$ Reaction employing DMOP. ${ }^{\mathrm{b}}$ Crude reaction mixture contains $\sim 5 \%$ benzoic acid. ${ }^{\mathrm{c}}$ Isolated as a $1: 1$ mixture of diastereoisomers. ${ }^{\mathrm{d}}$ Product contains $\sim 5 \%$ Knoevenagel product. ${ }^{\mathrm{e}} \mathrm{Aldol}$ addition reaction at $50{ }^{\circ} \mathrm{C}$ for 1 hour.

${ }^{a}$ Reaction employing DMOP. ${ }^{b}$ Crude reaction mixture contains $\sim 5 \%$ benzoic acid. ${ }^{c}$ Isolated as a $1: 1$ mixture of diastereoisomers. ${ }^{d}$ Product contains $\sim 5 \%$ Knoevenagel product. ${ }^{e}$ Aldol addition reaction at $50{ }^{\circ} \mathrm{C}$ for $1 \mathrm{~h}$.

Table 5. Tandem Acetalization-Direct Aldol Addition of Benzaldehyde with Acetyl Acetone ${ }^{a}$

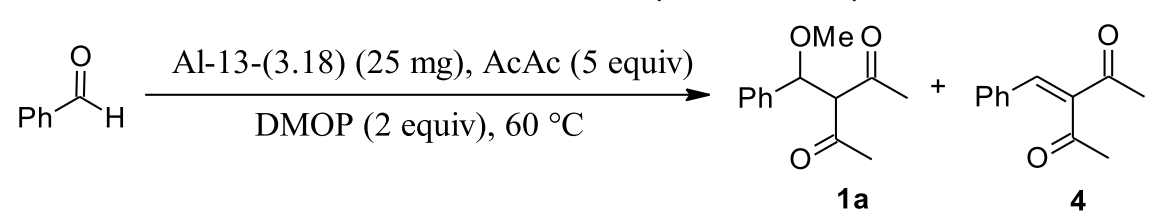

\begin{tabular}{|c|c|c|c|c|}
\hline entry & time $(\mathrm{h})$ & conversion $(\%)^{b}$ & yield 1a (\%) & selectivity $(\%)^{b, c}$ \\
\hline 1 & 0.5 & 87 & 26 & $100: 0$ \\
\hline 2 & 2 & 88 & 44 & $93: 7$ \\
\hline 3 & 4 & 91 & 52 & $83: 17$ \\
\hline 4 & 6 & 92 & 47 & $70: 30$ \\
\hline 5 & $4^{d}$ & 92 & 62 & 100:0 \\
\hline
\end{tabular}

${ }^{a}$ Experimental conditions: the catalyst $(25 \mathrm{mg})$ was added to a solution of benzaldehyde $(0.5 \mathrm{mmol})$, DMOP $(1 \mathrm{mmol})$, and AcAc ( $\left.2.5 \mathrm{mmol}\right)$ in a sealed reaction vessel and heated to $60^{\circ} \mathrm{C}$ with vigorous stirring. ${ }^{b}$ Determined by ${ }^{1} \mathrm{H}$ NMR spectroscopy on the crude reaction mixture. ${ }^{c} \mathrm{Ratio}$ of 1a to $4 .{ }^{d}$ Initial reaction at room temperature for $2 \mathrm{~h}$ followed by heating to $60{ }^{\circ} \mathrm{C}$ for $2 \mathrm{~h}$.

goal. First, a telescoped sequential reaction protocol, in which the acetal is generated from the corresponding aldehyde and an acetalization reagent, followed by addition of 1,3-dicarbonyl compound once the acetalization reaction is complete (Scheme 2: sequential approach). The second protocol involves a tandem approach, where all reagents are present at the beginning of the reaction, and the acetal substrate is generated in the presence of the 1,3-dicarbonyl compound (Scheme 2: tandem approach).

We initiated these studies by considering a sequential process, given our earlier successes in this area. As previously, the Al-13-(3.18) aluminosilicate material proved to be a highly efficient catalyst for acetal formation from a range of aldehydes in the presence of a small excess of either orthoesters, such as TMOF and triethyl orthoformate (TEOF), or DMOP, giving excellent conversion to the acetal either at room temperature, or more rapidly, at elevated temperatures. After removal of excess alcohol generated during the acetalization reaction, the acetal underwent rapid direct aldol reaction on addition of a range of 1,3-dicarbonyl compounds under our optimized reaction conditions to provide the addition products in yields similar to those obtained by reactions directly from the acetal (Table 4).

Finally, we investigated the possibility of carrying out the reaction as a one-pot, tandem process employing benzaldehyde and AcAc as a model reaction. To avoid any possibility of 
consuming the orthoformate in a competing reaction with AcAc, rather than the desired reaction with benzaldehyde, we selected DMOP as the reagent for the acetalization step. Under our optimized reaction conditions, the acetalization reaction proceeded rapidly with almost complete consumption of the aldehyde starting material within the first hour of reaction and provided significant quantities of the aldol addition product 1a (Table 5, entry 1). Extending reaction times led to improved conversions to 1a, however, significant quantities of the Knoevenagel product 4 were now observed in the ${ }^{1} \mathrm{H}$ NMR spectra of these crude reaction mixtures (entries 2-4). Presumably, maintaining the thermally unstable aldol product at elevated temperatures for prolonged periods of time is undesirable, leading to thermally promoted elimination of methanol from the initial aldol adduct 1a.

We reasoned that reducing the overall time spent at these elevated temperatures would prove beneficial minimizing the undesirable elimination reaction and leading to improvements in both selectivity and overall yield. We therefore next considered a strategy, in which the reaction was initially carried out at room temperature, to promote the initial acetalization reaction before increasing the temperature to promote the subsequent aldol addition reaction. As expected, reaction at room temperature over $2 \mathrm{~h}$ led to the formation of significant amounts of the acetal intermediate with only moderate quantities of the aldol addition product $(\sim 26 \%)$ observed. We were gratified to observe that on increasing the reaction temperature to $60{ }^{\circ} \mathrm{C}$, the conversion to $1 \mathrm{a}$ improved to $62 \%$ with only trace quantities of the competing Knoevenagel product being observed by ${ }^{1} \mathrm{H}$ NMR analysis of the crude reaction mixture (entry 5 ).

\section{CONCLUSIONS}

In summary, a novel and operationally simple direct aldol addition reaction of 1,3-dicarbonyl compounds with acetals has been developed, which avoids the requirement for the use of strong Lewis acid catalysts under strictly anhydrous or inert reaction conditions. The procedure employs a mildly acidic heterogeneous aluminosilicate catalyst, which is readily accessible using an evaporation-induced self-assembly (EISA) process, which requires no specialist equipment or techniques, and is fully recyclable. The protocol has been successfully applied to a range of acylic aromatic acetals and 1,3-dicarbonyl compounds providing the aldol addition products in high yield, with little of the competing Knoevenagel product being formed. The scope of this reaction can be further extended to encompass the reaction of aldehydes in novel telescoped acetalization-aldol addition processes, which capitalize on the ability of these nanoporous aluminosilicate materials to efficiently catalyze both the acetalization and subsequent direct aldol reactions. This methodology provides a useful alternative strategy for existing oxa-Michael protocols to access $\beta$ hydroxycarbonyl products employing a direct aldol strategy under mildly acidic conditions.

\section{EXPERIMENTAL SECTION}

General Methods. Acetyl acetone was dried and distilled prior to use. Other commercially available reagents were used without further purification. Acetal substrates were synthesized using literature procedures. ${ }^{47,55}$ All reactions performed in sealed screw-cap vials. Flash chromatography was carried out using Merck Kieselgel $60 \mathrm{H}$ silica. Analytical thin layer chromatography was carried out using commercially available aluminum-backed plates precoated with silica gel 60 F254 that were visualized under UV light (at $254 \mathrm{~nm}$ ). Infrared (IR) spectra were recorded in the range $4000-600 \mathrm{~cm}^{-1}$ as neat oils or solids and are reported in $\mathrm{cm}^{-1}$. Nuclear magnetic resonance (NMR) spectra were recorded at $400 \mathrm{MHz}$ in $\mathrm{CDCl}_{3}$ at $25{ }^{\circ} \mathrm{C}$ and are reported in ppm; $J$ values are recorded in $\mathrm{Hz}$ and multiplicities are expressed by the usual conventions. Low-resolution mass spectra (MS) were determined by electron impact ionization (EI). High-resolution mass spectra (HRMS) were obtained by courtesy of the EPSRC Mass Spectrometry Facility, Swansea University, U.K. using the specified ionization technique. Removal of solvent refers to evaporation at reduced pressure using a rotary evaporator followed by the removal of trace volatiles using a vacuum pump. All catalysts were stored at $120^{\circ} \mathrm{C}$ for at least $12 \mathrm{~h}$ prior to use.

Catalyst Preparation. A typical preparation for the synthesis of the aluminosilicate AS-13-(3.18) catalyst under EISA conditions is as follows: ${ }^{36,37}$ cetyltrimethylammonium bromide $(4.0 \mathrm{~g}, 11 \mathrm{mmol})$ was dissolved in a solution of hydrochloric acid $(2.5 \mathrm{~mL}, 0.1 \mathrm{M})$, ethanol $(17.5 \mathrm{~mL})$, and water $(22.5 \mathrm{~mL})$. Tetraethyl orthosilicate $(25 \mathrm{~mL}, 112 \mathrm{mmol})$ was added, and the mixture stirred for $10 \mathrm{~min}$ at $40{ }^{\circ} \mathrm{C}$. The solution was cooled to room temperature, and aluminum nitrate nonahydrate $(3.35 \mathrm{~g}, 8.95 \mathrm{mmol})$ was added in one portion. The mixture was stirred for $20 \mathrm{~min}$ and then left to age at room temperature for $24 \mathrm{~h}$. The resultant orange solid was crushed into a fine powder and calcined in air at $650{ }^{\circ} \mathrm{C}$ for $6 \mathrm{~h}$ to remove the organic template to give a fine white powder.

General Experimental Procedure 1: Reaction of Dicarbonyl Compounds with Acetals under SolventFree Conditions. The nanoporous aluminosilicate catalyst $(25 \mathrm{mg})$ was added to a solution of the desired acetal (0.5 $\mathrm{mmol}$ ) in the requisite dicarbonyl compound (5 equiv, 2.5 $\mathrm{mmol}$ ) in a screw-cap vial, and the mixture heated to $60{ }^{\circ} \mathrm{C}$ with vigorous stirring. After $30 \mathrm{~min}$, the reaction mixture was cooled to room temperature and the volatile components removed under a gentle stream of nitrogen for $1 \mathrm{~min}$. Where necessary, the corresponding orthoformate or acetal ( 0.5 equiv, $0.25 \mathrm{mmol}$ ) was then added, and heating continued for an additional $30 \mathrm{~min}$. On completion of the reaction, the catalyst was removed by filtration and washed with chloroform $(2 \times 2$ $\mathrm{mL}$ ) to provide the crude aldol product, which was purified by column chromatography (hexane $\rightarrow$ hexane/diethyl ether 80:20).

General Experimental Procedure 2: Telescoped Sequential Acetalization-Aldol Addition Reactions of Dicarbonyl Compounds. The nanoporous aluminosilicate catalyst $(25 \mathrm{mg})$ was added to a solution of the desired aldehyde $(0.5 \mathrm{mmol})$ in the requisite orthoformate or ketal $(2$ equiv, $1 \mathrm{mmol}$ ) in a screw-cap vial, and the mixture heated to $60{ }^{\circ} \mathrm{C}$ with vigorous stirring. After $30 \mathrm{~min}$, the reaction mixture was cooled to room temperature and the volatile components removed under a gentle stream of nitrogen for $1 \mathrm{~min}$. The corresponding dicarbonyl compound ( 5 equiv, $2.5 \mathrm{mmol}$ ) was then added and heating continued. On completion of the reaction, the product was isolated and purified as described above.

3-[Methoxy(phenyl)methyl]pentane-2,4-dione (1a). Reaction of benzaldehyde dimethyl acetal $(76 \mathrm{mg}, 0.5 \mathrm{mmol})$ and acetyl acetone $(250 \mathrm{mg}, 2.5 \mathrm{mmol})$ according to general 
procedure 1 gave ether 1a (94 mg, 85\%) as a light yellow oil. ${ }^{1} \mathrm{H}$ NMR (400 MHz, $\left.\mathrm{CDCl}_{3}\right) \delta=7.30-7.25(\mathrm{~m}, 5 \mathrm{H}), 4.75(\mathrm{~d}$, $J=10.5 \mathrm{~Hz}, 1 \mathrm{H}), 4.05(\mathrm{~d}, J=10.5 \mathrm{~Hz}, 1 \mathrm{H}), 3.05(\mathrm{~s}, 3 \mathrm{H}), 2.25$ (s, 3H), $1.75(\mathrm{~s}, 3 \mathrm{H}) ;{ }^{13} \mathrm{C} \mathrm{NMR}\left(100 \mathrm{MHz}, \mathrm{CDCl}_{3}\right) \delta=201.8$, 201.2, 138.1, 128.7, 128.6, 127.5, 82.3, 76.1, 56.4, 31.2, 28.9; LRMS (EI) $m / z 238\left[\mathrm{M}+\mathrm{NH}_{4}\right]^{+}$; HRMS (FTMS-NSI) calculated for $\mathrm{C}_{13} \mathrm{H}_{20} \mathrm{NO}_{3}\left[\mathrm{M}+\mathrm{NH}_{4}\right]^{+}$238.1438, found 238.1439; IR (ATR) $/ \mathrm{cm}^{-1}$ : 2927, 1701, 1355, 1151, 1089.

3-[Ethoxy(phenyl)methyl]pentane-2,4-dione (1b). Reaction of benzaldehyde diethyl acetal $(90 \mathrm{mg}, 0.5 \mathrm{mmol})$ and acetyl acetone $(250 \mathrm{mg}, 2.5 \mathrm{mmol}$ ) according to general procedure 1 gave ether $\mathbf{1 b}(101 \mathrm{mg}, 86 \%)$ as a light yellow oil. ${ }^{1} \mathrm{H}$ NMR (400 MHz, $\left.\mathrm{CDCl}_{3}\right) \delta=7.30-7.25(\mathrm{~m}, 5 \mathrm{H}), 4.90(\mathrm{~d}$, $J=10.5 \mathrm{~Hz}, 1 \mathrm{H}), 4.10(\mathrm{~d}, J=10.5 \mathrm{~Hz}, 1 \mathrm{H}), 3.30-3.20(\mathrm{~m}$, $2 \mathrm{H}), 2.30(\mathrm{~s}, 3 \mathrm{H}), 1.80(\mathrm{~s}, 3 \mathrm{H}), 1.05(\mathrm{t}, J=7 \mathrm{~Hz}, 3 \mathrm{H}) ;{ }^{13} \mathrm{C}$ NMR $\left(100 \mathrm{MHz}, \mathrm{CDCl}_{3}\right) \delta=201.9,201.4,138.9,128.6$, 128.5, 127.4, 80.5, 76.1, 64.1, 31.3, 29.0, 15.0; LRMS (EI) $\mathrm{m} / z$ $234[\mathrm{M}]^{+}$; HRMS (FTMS-NSI) calculated for $\mathrm{C}_{12} \mathrm{H}_{13} \mathrm{O}_{2}$ [M$\mathrm{EtOH}+\mathrm{H}]^{+}$189.0910, found 189.0906; IR (ATR) $/ \mathrm{cm}^{-1}$ : 2975, 1700, 1354, 1153, 1087.

3-[Propoxy(phenyl)methyl]pentane-2,4-dione (1c). Reaction of benzaldehyde dipropyl acetal $(104 \mathrm{mg}, 0.5 \mathrm{mmol})$ and acetyl acetone (250 mg, $2.5 \mathrm{mmol}$ ) according to general procedure 1 gave ether $1 \mathrm{c}(103 \mathrm{mg}, 83 \%)$ as a colorless oil. ${ }^{1} \mathrm{H}$ NMR $\left(400 \mathrm{MHz}, \mathrm{CDCl}_{3}\right) \delta=7.30-7.25(\mathrm{~m}, 5 \mathrm{H}), 4.90(\mathrm{~d}, J=$ $10.5 \mathrm{~Hz}, 1 \mathrm{H}), 4.15(\mathrm{~d}, J=10.5 \mathrm{~Hz}, 1 \mathrm{H}), 3.10-3.20(\mathrm{~m}, 2 \mathrm{H})$, $2.32(\mathrm{~s}, 3 \mathrm{H}), 1.85(\mathrm{~s}, 3 \mathrm{H}), 1.50(\mathrm{hex}, J=7 \mathrm{~Hz}, 2 \mathrm{H}), 0.80(\mathrm{t}, J$ $=7 \mathrm{~Hz}, 3 \mathrm{H}) ;{ }^{13} \mathrm{C} \mathrm{NMR}\left(100 \mathrm{MHz}, \mathrm{CDCl}_{3}\right) \delta=201.9,201.3$, 138.9, 128.6, 128.4, 127.4, 80.8, 76.1, 70.4, 31.2, 29.1, 22.8, 10.6; LRMS (ESI) $m / z 266\left[\mathrm{M}+\mathrm{NH}_{4}\right]^{+}$; HRMS (FTMSNSI) calculated for $\mathrm{C}_{15} \mathrm{H}_{20} \mathrm{O}_{3} \mathrm{Na}[\mathrm{M}+\mathrm{Na}]^{+} 271.1305$, found 271.1303; IR (ATR)/ $\mathrm{cm}^{-1}$ : 2963, 1699, 1354, 1153, 1085.

3-[Methoxy(4-methylphenyl)methyl]pentane-2,4-dione (1d). Reaction of 4-methylbenzaldehyde dimethyl acetal (90 $\mathrm{mg}, 0.5 \mathrm{mmol})$ and acetyl acetone $(250 \mathrm{mg}, 2.5 \mathrm{mmol})$ according to general procedure 1 gave ether $1 \mathrm{~d}(100 \mathrm{mg}, 85 \%)$ as a yellow oil. ${ }^{1} \mathrm{H} \mathrm{NMR}\left(400 \mathrm{MHz}, \mathrm{CDCl}_{3}\right) \delta=7.21(\mathrm{~d}, J=9$ $\mathrm{Hz}, 2 \mathrm{H}), 7.15$ (d, $J=9 \mathrm{~Hz}, 2 \mathrm{H}), 4.75(\mathrm{~d}, J=10.5 \mathrm{~Hz}, 1 \mathrm{H})$, $4.15(\mathrm{~d}, J=10.5 \mathrm{~Hz}, 1 \mathrm{H}), 3.10(\mathrm{~s}, 3 \mathrm{H}), 2.32(\mathrm{~s}, 3 \mathrm{H}), 2.30(\mathrm{~s}$, $3 \mathrm{H}), 1.85(\mathrm{~s}, 3 \mathrm{H}) ;{ }^{13} \mathrm{C}$ NMR $\left(100 \mathrm{MHz}, \mathrm{CDCl}_{3}\right) \delta=202.0$, 201.3, 138.4, 134.9, 129.4, 127.4, 82.1, 76.1, 56.2, 31.1, 28.9, 21.1; LRMS (EI) $m / z 252\left[\mathrm{M}+\mathrm{NH}_{4}\right]^{+}$; HRMS (FTMSNSI) calculated for $\mathrm{C}_{14} \mathrm{H}_{22} \mathrm{NO}_{3}\left[\mathrm{M}+\mathrm{NH}_{4}\right]^{+} 252.1594$, found 252.1593; IR (ATR) $/ \mathrm{cm}^{-1}$ : 2927, 1699, 1355, 1151, 1082.

3-[Ethoxy(4-methylphenyl)methyl]pentane-2,4-dione (1e). Reaction of 4-methylbenzaldehyde diethyl acetal $(97 \mathrm{mg}$, $0.5 \mathrm{mmol}$ ) and acetyl acetone $(250 \mathrm{mg}, 2.5 \mathrm{mmol}$ ) according to general procedure 1 gave ether $1 \mathrm{e}(97 \mathrm{mg}, 78 \%)$ as a light yellow oil. ${ }^{1} \mathrm{H}$ NMR $\left(400 \mathrm{MHz}, \mathrm{CDCl}_{3}\right) \delta=7.20(\mathrm{~d}, J=9 \mathrm{~Hz}$, $2 \mathrm{H}), 7.10(\mathrm{~d}, J=9 \mathrm{~Hz}, 2 \mathrm{H}), 4.85(\mathrm{~d}, J=10.5 \mathrm{~Hz}, 1 \mathrm{H}), 4.10(\mathrm{~d}$, $J=10.5 \mathrm{~Hz}, 1 \mathrm{H}), 3.20-3.30(\mathrm{~m}, 2 \mathrm{H}), 2.32(\mathrm{~s}, 3 \mathrm{H}), 2.30(\mathrm{~s}$, $3 \mathrm{H}), 1.85(\mathrm{~s}, 3 \mathrm{H}), 1.05(\mathrm{t}, J=7 \mathrm{~Hz}, 3 \mathrm{H}) ;{ }^{13} \mathrm{C} \mathrm{NMR}(100$ $\left.\mathrm{MHz}, \mathrm{CDCl}_{3}\right) \delta=202.0,201.4,138.2,135.7,129.3,127.3$, 80.4, 76.1, 63.9, 31.2, 29.0, 21.1, 15.0; LRMS (EI) $\mathrm{m} / z 266$ [M $\left.+\mathrm{NH}_{4}\right]^{+}$; HRMS (FTMS-NSI) calculated for $\mathrm{C}_{15} \mathrm{H}_{20} \mathrm{O}_{3} \mathrm{Na}$ $[\mathrm{M}+\mathrm{Na}]^{+}$271.1305, found 271.1302; IR (ATR) $/ \mathrm{cm}^{-1}: 2978$, $1699,1356,1155,1089$.

3-[Methoxy(4-methoxyphenyl)methyl]pentane-2,4-dione (1f). Reaction of 4-methoxybenzaldehyde dimethyl acetal (91 $\mathrm{mg}, 0.5 \mathrm{mmol}$ ) and acetyl acetone $(250 \mathrm{mg}, 2.5 \mathrm{mmol})$ according to general procedure 1 gave ether 1 ff $(94 \mathrm{mg}, 75 \%)$ as a yellow oil. ${ }^{1} \mathrm{H} \mathrm{NMR}\left(400 \mathrm{MHz}, \mathrm{CDCl}_{3}\right) \delta=7.25(\mathrm{~d}, J=9$ $\mathrm{Hz}, 2 \mathrm{H}), 6.85$ (d, $J=9 \mathrm{~Hz}, 2 \mathrm{H}), 4.75$ (d, $J=10.5 \mathrm{~Hz}, 1 \mathrm{H})$, $4.10(\mathrm{~d}, J=10.5 \mathrm{~Hz}, 1 \mathrm{H}), 3.75(\mathrm{~s}, 3 \mathrm{H}), 3.10(\mathrm{~s}, 3 \mathrm{H}), 2.30(\mathrm{~s}$, $3 \mathrm{H}), 1.85(\mathrm{~s}, 3 \mathrm{H}) ;{ }^{13} \mathrm{C} \mathrm{NMR}\left(100 \mathrm{MHz}, \mathrm{CDCl}_{3}\right) \delta=202.0$, 201.3, 159.8, 129.9, 128.7, 114.0, 81.9, 76.1, 56.1, 55.1, 31.1, 28.9; LRMS (EI) $m / z 250[\mathrm{M}]^{+}$; HRMS (FTMS-NSI) calculated for $\mathrm{C}_{13} \mathrm{H}_{15} \mathrm{O}_{3}[\mathrm{M}-\mathrm{MeOH}+\mathrm{H}]^{+}$219.1016, found 219.1014; IR (ATR)/cm $\mathrm{cm}^{-1}$ : 2936, 1699, 1355, 1173, 1080.

3-[Ethoxy(4-methoxyphenyl)methyl]pentane-2,4-dione (1g). Reaction of 4-methoxybenzaldehyde diethyl acetal (105 $\mathrm{mg}, 0.5 \mathrm{mmol})$ and acetyl acetone $(250 \mathrm{mg}, 2.5 \mathrm{mmol})$ according to general procedure 1 gave ether $1 \mathrm{~g}(96 \mathrm{mg}, 73 \%)$ as a light yellow oil. ${ }^{1} \mathrm{H} \mathrm{NMR}\left(400 \mathrm{MHz}, \mathrm{CDCl}_{3}\right) \delta=7.20(\mathrm{~d}$, $J=9 \mathrm{~Hz}, 2 \mathrm{H}), 6.80(\mathrm{~d}, J=9 \mathrm{~Hz}, 2 \mathrm{H}), 4.75(\mathrm{~d}, J=10.5 \mathrm{~Hz}$, $1 \mathrm{H}), 4.05(\mathrm{~d}, J=10.5 \mathrm{~Hz}, 1 \mathrm{H}), 3.70(\mathrm{~s}, 3 \mathrm{H}), 3.15-3.20(\mathrm{~m}$, $2 \mathrm{H}), 2.25(\mathrm{~s}, 3 \mathrm{H}), 1.75(\mathrm{~s}, 3 \mathrm{H}), 1.00(\mathrm{t}, J=7 \mathrm{~Hz}, 3 \mathrm{H}) ;{ }^{13} \mathrm{C}$ NMR $\left(100 \mathrm{MHz}, \mathrm{CDCl}_{3}\right) \delta=202.1,201.5,159.6,129.9$, 128.6, 113.9, 80.1, 76.1, 63.8, 55.2, 31.2, 29.0, 14.9; LRMS (ESI) $m / z 282\left[\mathrm{M}+\mathrm{NH}_{4}\right]^{+}$; HRMS (FTMS-NSI) calculated for $\mathrm{C}_{15} \mathrm{H}_{20} \mathrm{O}_{4} \mathrm{Na}[\mathrm{M}+\mathrm{Na}]^{+}$287.1254, found 287.1250; IR (ATR) $/ \mathrm{cm}^{-1}: 2976,1698,1356,1173,1087$.

3-[Ethoxy(3-methoxyphenyl)methyl]pentane-2,4-dione (1h). Reaction of 3-methoxybenzaldehyde diethyl acetal (105 $\mathrm{mg}, 0.5 \mathrm{mmol}$ ) and acetyl acetone $(250 \mathrm{mg}, 2.5 \mathrm{mmol}$ ) according to general procedure 1 gave ether $1 \mathrm{~h}(105 \mathrm{mg}, 80 \%)$ as a colorless oil. ${ }^{1} \mathrm{H} \mathrm{NMR}\left(400 \mathrm{MHz}, \mathrm{CDCl}_{3}\right) \delta=7.20-7.25$ (m, 1H), 6.90-6.95 (m, 2H), 6.80-6.85 (m, 1H), $4.90(\mathrm{~d}, J=$ $10.5 \mathrm{~Hz}, 1 \mathrm{H}), 4.15$ (d, $J=10.5 \mathrm{~Hz}, 1 \mathrm{H}), 3.85$ (s, 3H), 3.25$3.35(\mathrm{~m}, 2 \mathrm{H}), 2.35(\mathrm{~s}, 3 \mathrm{H}), 1.90(\mathrm{~s}, 3 \mathrm{H}), 1.25(\mathrm{t}, J=7 \mathrm{~Hz}$, $3 \mathrm{H}) ;{ }^{13} \mathrm{C} \mathrm{NMR}\left(100 \mathrm{MHz}, \mathrm{CDCl}_{3}\right) \delta=202.0,201.4,159.8$, $140.6,129.7,119.8,114.0,112.6,80.4,76.1,64.2,55.2,31.4$, 28.9, 15.0; LRMS (ESI) $m / z 282\left[\mathrm{M}+\mathrm{NH}_{4}\right]^{+}$; HRMS (TOFASAP) calculated for $\mathrm{C}_{15} \mathrm{H}_{24} \mathrm{NO}_{4}\left[\mathrm{M}+\mathrm{NH}_{4}\right]^{+}$282.1705, found 282.1699; IR (ATR) $/ \mathrm{cm}^{-1}$ : 2976, 1699, 1357, 1155, 1097.

3-[Ethoxy(4-bromophenyl)methyl]pentane-2,4-dione (1i). Reaction of 4-bromobenzaldehyde diethyl acetal (129 mg, 0.5 $\mathrm{mmol}$ ) and acetyl acetone $(250 \mathrm{mg}, 2.5 \mathrm{mmol}$ ) according to general procedure 1 gave ether $1 \mathbf{i}(137 \mathrm{mg}, 88 \%)$ as a yellow oil. ${ }^{1} \mathrm{H}$ NMR (400 MHz, $\left.\mathrm{CDCl}_{3}\right) \delta=7.50(\mathrm{~d}, J=9 \mathrm{~Hz}, 2 \mathrm{H})$, $7.20(\mathrm{~d}, J=9 \mathrm{~Hz}, 2 \mathrm{H}), 4.90(\mathrm{~d}, J=10.5 \mathrm{~Hz}, 1 \mathrm{H}), 4.10(\mathrm{~d}, J=$ $10.5 \mathrm{~Hz}, 1 \mathrm{H}), 3.25-3.30(\mathrm{~m}, 2 \mathrm{H}), 2.30(\mathrm{~s}, 3 \mathrm{H}), 1.90(\mathrm{~s}, 3 \mathrm{H})$, $1.05(\mathrm{t}, J=7 \mathrm{~Hz}, 3 \mathrm{H}) ;{ }^{13} \mathrm{C}$ NMR $\left(100 \mathrm{MHz} \mathrm{CDCl}_{3}\right) \delta=$ 201.4, 201.0, 138.1, 131.8, 129.1, 122.4, 79.8, 76.1, 64.4, 31.2, 29.0, 14.9; LRMS (ESI) $m / z 330-332\left[\mathrm{M}+\mathrm{NH}_{4}\right]^{+}$; HRMS (FTMS-NSI) calculated for $\mathrm{C}_{14} \mathrm{H}_{17} \mathrm{O}_{3} \mathrm{Br}^{79} \mathrm{Na}[\mathrm{M}+\mathrm{Na}]^{+}$ 335.0253, found 335.0250; IR (ATR) $/ \mathrm{cm}^{-1}$ : 2976, 1700, 1355, 1155, 1085.

3-[Ethoxy(4-nitrophenyl)methyl]pentane-2,4-dione (1j). Reaction of 4-nitrobenzaldehyde diethyl acetal $(113 \mathrm{mg}, 0.5$ $\mathrm{mmol}$ ) and acetyl acetone $(250 \mathrm{mg}, 2.5 \mathrm{mmol}$ ) according to general procedure 1 gave ether $1 \mathbf{j}(112 \mathrm{mg}, 80 \%)$ as a colorless oil. ${ }^{1} \mathrm{H}$ NMR (400 MHz, $\left.\mathrm{CDCl}_{3}\right) \delta=8.25(\mathrm{~d}, J=9 \mathrm{~Hz}, 2 \mathrm{H})$, $7.55(\mathrm{~d}, J=9 \mathrm{~Hz}, 2 \mathrm{H}), 5.10(\mathrm{~d}, J=10.5 \mathrm{~Hz}, 1 \mathrm{H}), 4.15$ (d, $J=$ $10.5 \mathrm{~Hz}, 1 \mathrm{H}), 3.30-3.35(\mathrm{~m}, 2 \mathrm{H}), 2.35(\mathrm{~s}, 3 \mathrm{H}), 1.95(\mathrm{~s}, 3 \mathrm{H})$, $1.15(\mathrm{t}, J=7 \mathrm{~Hz}, 3 \mathrm{H}) ;{ }^{13} \mathrm{C}$ NMR $\left(100 \mathrm{MHz} \mathrm{CDCl}_{3}\right) \delta=$ 200.7, 200.5, 148.0, 146.7, 128.4, 123.8, 79.4, 75.8, 64.9, 31.1, 29.2, 14.9; LRMS (TOF-ASAP) $m / z 279[\mathrm{M}]^{+}$; HRMS (TOFASAP) calculated for $\mathrm{C}_{14} \mathrm{H}_{16} \mathrm{NO}_{5}[\mathrm{M}-\mathrm{H}]^{+} 278.1028$, found 278.1021; IR (ATR) $/ \mathrm{cm}^{-1}$ : 2977, 1728, 1700, 1519, 1345, 1155, 1087.

Ethyl 2-[Methoxy(phenyl)methyl]-3-oxobutanoate (as an Inseparable 1:1 Mixture of Diasteroisomers) (2a). Reaction of benzaldehyde dimethyl acetal $(76 \mathrm{mg}, 0.5 \mathrm{mmol})$ and ethyl acetoacetate $(325 \mathrm{mg}, 2.5 \mathrm{mmol}$ ) according to general 
procedure 1 gave ether $\mathbf{2 a}(91 \mathrm{mg}, 73 \%)$ as a colorless oil. ${ }^{1} \mathrm{H}$ NMR (400 MHz, $\left.\mathrm{CDCl}_{3}\right) \delta=7.30-7.35(\mathrm{~m}, 5 \mathrm{H}), 4.80$ and $4.75(\mathrm{~d}, J=11 \mathrm{~Hz}, 1 \mathrm{H}), 4.25-4.30(\mathrm{~m}, 1 \mathrm{H}), 3.90-4.00(\mathrm{~m}$, $2 \mathrm{H}), 3.15$ and $3.20(\mathrm{~s}, 3 \mathrm{H}), 1.90$ and $2.35(\mathrm{~s}, 3 \mathrm{H}), 1.00$ and $1.30(\mathrm{t}, J=7 \mathrm{~Hz}, 3 \mathrm{H}) ;{ }^{13} \mathrm{C}$ NMR $\left(100 \mathrm{MHz}, \mathrm{CDCl}_{3}\right) \delta=$ 201.3, 200.5, 167.2, 166.3, 138.1, 138.0, 128.6, $128.5(2 \times)$, 128.4, 127.7, 82.1, 81.6, 67.3, 66.9, 56.7, 56.6, 30.9, 30.2, 14.1, 13.1; LRMS (ESI) $\mathrm{m} / z 268\left[\mathrm{M}+\mathrm{NH}_{4}\right]^{+}$; HRMS (FTMSNSI) calculated for $\mathrm{C}_{14} \mathrm{H}_{22} \mathrm{NO}_{4}\left[\mathrm{M}+\mathrm{NH}_{4}\right]^{+} 268.1543$, found 268.1546; IR (ATR) $/ \mathrm{cm}^{-1}$ : 2983, 1745, 1716, 1356, 1154, 1067.

Ethyl 2-[Ethoxy(phenyl)methyl]-3-oxobutanoate (as an Inseparable 1:1 Mixture of Diasteroisomers) (2b). Reaction of benzaldehyde diethyl acetal $(90 \mathrm{mg}, 0.5 \mathrm{mmol})$ and ethyl acetoacetate (325 mg, $2.5 \mathrm{mmol}$ ) according to general procedure 1 gave ether $\mathbf{2 b}(119 \mathrm{mg}, 90 \%)$ as a light yellow oil. ${ }^{1} \mathrm{H}$ NMR (400 MHz, $\left.\mathrm{CDCl}_{3}\right) \delta=7.35-7.30(\mathrm{~m}, 5 \mathrm{H}), 4.80$ and $4.75(\mathrm{~d}, J=10.5 \mathrm{~Hz}, 1 \mathrm{H}), 4.25-4.30(\mathrm{~m}, 1 \mathrm{H}), 3.90-3.95$ $(\mathrm{m}, 2 \mathrm{H}), 3.30-3.35(\mathrm{~m}, 2 \mathrm{H}), 1.90$ and $2.40(\mathrm{~s}, 3 \mathrm{H}), 1.00$ and $1.30(\mathrm{t}, J=7 \mathrm{~Hz}, 3 \mathrm{H}), 1.10(\mathrm{t}, J=7 \mathrm{~Hz}, 3 \mathrm{H}) ;{ }^{13} \mathrm{C}$ NMR $(100$ $\left.\mathrm{MHz}, \mathrm{CDCl}_{3}\right) \delta=201.4,200.6,167.2,166.4,138.9,138.8$, 128.6, 128.5, 128.4, 128.3, $127.6(2 \times)$, 80.3, 79.8, 67.5, 67.0, 64.4, 64.3, 61.5, 61.2, 31.0, 30.3, 15.0 (2×), 14.1, 13.8; LRMS (ESI) $\mathrm{m} / z 282\left[\mathrm{M}+\mathrm{NH}_{4}\right]^{+}$; HRMS (FTMS-NSI) calculated for $\mathrm{C}_{15} \mathrm{H}_{20} \mathrm{O}_{4} \mathrm{Na}[\mathrm{M}+\mathrm{Na}]^{+} 287.1254$, found 287.1251; IR (ATR) $/ \mathrm{cm}^{-1}$ : 2978, 1746, 1718, 1356, 1179, 1094.

Ethyl 2-[Ethoxy(4-methylphenyl)methyl]-3-oxobutanoate (as an Inseparable 1:1 Mixture of Diasteroisomers) (2c). Reaction of 4-methylbenzaldehyde $(60 \mathrm{mg}, 0.5 \mathrm{mmol})$, TEOF $(148 \mathrm{mg}, 1 \mathrm{mmol})$ and ethyl acetoacetate $(325 \mathrm{mg}, 2.5 \mathrm{mmol})$ according to general procedure 2 gave ether $2 \mathrm{c}(104 \mathrm{mg}, 75 \%)$ as a colorless oil. ${ }^{1} \mathrm{H}$ NMR $\left(400 \mathrm{MHz}, \mathrm{CDCl}_{3}\right) \delta=7.20(\mathrm{~d}, J=$ $9 \mathrm{~Hz}, 2 \mathrm{H}), 7.05$ (d, $J=9 \mathrm{~Hz}, 2 \mathrm{H}), 4.75$ and $4.80(\mathrm{~d}, J=11 \mathrm{~Hz}$, $1 \mathrm{H}), 4.10-4.20(\mathrm{~m}, 1 \mathrm{H}), 3.80-3.90(\mathrm{~m}, 2 \mathrm{H}), 3.20-3.25(\mathrm{~m}$, $2 \mathrm{H}), 1.80$ and $2.30(\mathrm{~s}, 3 \mathrm{H}), 2.20(\mathrm{~s}, 3 \mathrm{H}), 1.00(\mathrm{t}, J=7 \mathrm{~Hz}$, $3 \mathrm{H}), 0.90-0.95(\mathrm{~m}, 3 \mathrm{H}) ;{ }^{13} \mathrm{C}$ NMR $\left(100 \mathrm{MHz}, \mathrm{CDCl}_{3}\right) \delta=$ 201.5, 200.6, 167.3, 166.5, 138.1, 138.0, 129.2, 129.0, 127.5, $127.4,80.1,79.6,67.5,67.0,64.2,64.1,61.4,61.1,30.9,30.2$, $21.1,15.0,14.9,14.1,13.8$; LRMS (ESI) $m / z 296[\mathrm{M}+$ $\left.\mathrm{NH}_{4}\right]^{+}$; HRMS (FTMS-NSI) calculated for $\mathrm{C}_{16} \mathrm{H}_{26} \mathrm{NO}_{4}[\mathrm{M}+$ $\left.\mathrm{NH}_{4}\right]^{+}$296.1856, found 296.1850; IR (ATR) $/ \mathrm{cm}^{-1}$ : 2979, 1744, 1715, 1368, 1143, 1040.

Ethyl 2-[Ethoxy(4-methoxylphenyl)methyl]-3-oxobutanoate (as an Inseparable 1:1 Mixture of Diasteroisomers) (2d). Reaction of 4-methoxybenzaldehyde $(68 \mathrm{mg}, 0.5 \mathrm{mmol})$, TEOF (148 mg, $1 \mathrm{mmol}$ ) and ethyl acetoacetate $(325 \mathrm{mg}, 2.5$ $\mathrm{mmol})$ according to general procedure 2 gave ether $2 \mathrm{~d}(125$ $\mathrm{mg}, 85 \%)$ as a light yellow oil. ${ }^{1} \mathrm{H} \mathrm{NMR}\left(400 \mathrm{MHz}, \mathrm{CDCl}_{3}\right) \delta$ $=7.25(\mathrm{~d}, J=9 \mathrm{~Hz}, 2 \mathrm{H}), 6.85(\mathrm{~d}, J=9 \mathrm{~Hz}, 2 \mathrm{H}), 4.80$ and 4.85 (d, $J=11 \mathrm{~Hz}, 1 \mathrm{H}), 4.20-4.25(\mathrm{~m}, 1 \mathrm{H}), 3.85-3.95(\mathrm{~m}, 2 \mathrm{H})$, $3.80(\mathrm{~s}, 3 \mathrm{H}), 3.25-3.35(\mathrm{~m}, 2 \mathrm{H}), 1.90$ and $2.35(\mathrm{~s}, 3 \mathrm{H}), 1.05$ and $1.25(\mathrm{t}, J=7 \mathrm{~Hz}, 3 \mathrm{H}), 1.05(\mathrm{t}, J=7 \mathrm{~Hz}, 3 \mathrm{H}) ;{ }^{13} \mathrm{C} \mathrm{NMR}$ $\left(100 \mathrm{MHz} \mathrm{CDCl}_{3}\right) \delta=201.6,200.7,167.3,166.5,159.6$, $130.8(2 \times), 128.8(2 \times), 113.9,113.7,79.8,79.3,67.5,67.0$, 64.1, 64.0, 61.4, 61.1, 55.2, 30.9, 30.3, 15.0, 14.9, 14.1, 13.8; LRMS (ESI) $m / z 312\left[\mathrm{M}+\mathrm{NH}_{4}\right]^{+}$; HRMS (FTMS-NSI) calculated for $\mathrm{C}_{16} \mathrm{H}_{26} \mathrm{NO}_{5}\left[\mathrm{M}+\mathrm{NH}_{4}\right]^{+} 312.1805$, found 312.1804; IR (ATR) $/ \mathrm{cm}^{-1}$ : 2979, 1745, 1716, 1511, 1355, 1247, 1173, 1086.

Dimethyl [Ethoxy(phenyl)methyl]propanedioate (3a). Reaction of benzaldehyde diethyl acetal $(90 \mathrm{mg}, 0.5 \mathrm{mmol})$ and dimethyl malonate (400 mg, $2.5 \mathrm{mmol}$ ) according to general procedure 1 gave ether $3 \mathrm{a}(117 \mathrm{mg}, 88 \%)$ as a colorless oil. ${ }^{1} \mathrm{H}$
NMR (400 MHz, $\left.\mathrm{CDCl}_{3}\right) \delta=7.30-7.40(\mathrm{~m}, 5 \mathrm{H}), 4.90(\mathrm{~d}, J=$ $10.5 \mathrm{~Hz}, 1 \mathrm{H}), 3.75-3.80(\mathrm{~m}, 4 \mathrm{H}), 3.50(\mathrm{~s}, 3 \mathrm{H}), 3.35-3.40$ $(\mathrm{m}, 2 \mathrm{H}), 1.15(\mathrm{t}, J=7 \mathrm{~Hz}, 3 \mathrm{H}) ;{ }^{13} \mathrm{C} \mathrm{NMR}\left(100 \mathrm{MHz} \mathrm{CDCl}_{3}\right)$ $\delta=167.7,166.7,138.6,128.5,128.4,127.5,79.9,64.6,59.9$, 52.6, 52.3, 15.0; LRMS (ESI) $m / z 284\left[\mathrm{M}+\mathrm{NH}_{4}\right]^{+}$; HRMS (FTMS-NSI) calculated for $\mathrm{C}_{14} \mathrm{H}_{19} \mathrm{O}_{5}[\mathrm{M}+\mathrm{H}]^{+}$267.1227, found 267.1227; IR (ATR) $/ \mathrm{cm}^{-1}$ : 2927, 1736, 1436, 1268, 1147, 1096.

Dimethyl [Ethoxy(4-methylphenyl)methyl]propanedioate (3b). Reaction of 4-methylbenzaldehyde diethyl acetal (97 mg, $0.5 \mathrm{mmol}$ ) and dimethyl malonate (400 $\mathrm{mg}, 2.5 \mathrm{mmol}$ ) according to general procedure 1 gave ether $3 \mathbf{b}(119 \mathrm{mg}, 85 \%)$ as a colorless oil. ${ }^{1} \mathrm{H}$ NMR $\left(400 \mathrm{MHz}, \mathrm{CDCl}_{3}\right) \delta=7.25(\mathrm{~d}, J=$ $9 \mathrm{~Hz}, 2 \mathrm{H}), 7.15(\mathrm{~d}, J=9 \mathrm{~Hz}, 2 \mathrm{H}), 4.90(\mathrm{~d}, J=10.5 \mathrm{~Hz}, 1 \mathrm{H})$, 3.75-3.85 (m, 4H), $3.50(\mathrm{~s}, 3 \mathrm{H}), 3.35-3.40(\mathrm{~m}, 2 \mathrm{H}), 2.35(\mathrm{~s}$, $3 \mathrm{H}), 1.15(\mathrm{t}, J=7 \mathrm{~Hz}, 3 \mathrm{H}) ;{ }^{13} \mathrm{C} \mathrm{NMR}\left(100 \mathrm{MHz}, \mathrm{CDCl}_{3}\right) \delta=$ 167.8, 166.7, 138.2, 135.5, 129.1, 127.5, 79.7, 64.4, 59.9, 52.6, 52.3, 21.2, 15.0; LRMS (ESI) $m / z 298\left[\mathrm{M}+\mathrm{NH}_{4}\right]^{+}$; HRMS (FTMS-NSI) calculated for $\mathrm{C}_{13} \mathrm{H}_{15} \mathrm{O}_{4}[\mathrm{M}-\mathrm{EtOH}+\mathrm{H}]^{+}$ 235.0965, found 235.0966; IR (ATR) $/ \mathrm{cm}^{-1}$ : 2927, 1738, 1434, 1264, 1131, 1091.

Dimethyl [Ethoxy(4-methoxylphenyl)methyl]propanedioate (3c). Reaction of 4-methoxybenzaldehyde $(68 \mathrm{mg}, 0.5 \mathrm{mmol})$, TEOF (148 mg, $1 \mathrm{mmol})$ and dimethyl malonate $(400 \mathrm{mg}, 2.5 \mathrm{mmol}$ ) according to general procedure 2 gave ether $3 \mathrm{c}(133 \mathrm{mg}, 90 \%)$ as a colorless oil. ${ }^{1} \mathrm{H}$ NMR $\left(400 \mathrm{MHz}, \mathrm{CDCl}_{3}\right) \delta=7.30(\mathrm{~d}, J=9 \mathrm{~Hz}, 2 \mathrm{H}), 6.90(\mathrm{~d}, J=9$ $\mathrm{Hz}, 2 \mathrm{H}), 4.85(\mathrm{~d}, J=10.5 \mathrm{~Hz}, 1 \mathrm{H}), 3.75-3.80(\mathrm{~m}, 7 \mathrm{H}), 3.50$ (s, 3H), 3.30-3.40 (m, 2H), $1.15(\mathrm{t}, J=7 \mathrm{~Hz}, 3 \mathrm{H}) ;{ }^{13} \mathrm{C}$ NMR $\left(100 \mathrm{MHz}, \mathrm{CDCl}_{3}\right) \delta=167.8,166.7,159.6,130.5,128.7$, 113.8, 79.5, 64.3, 60.0, 55.2, 52.6, 52.4, 15.0; LRMS (ESI) $m / z$ $314\left[\mathrm{M}+\mathrm{NH}_{4}\right]^{+}$; HRMS (FTMS-NSI) calculated for $\mathrm{C}_{15} \mathrm{H}_{24} \mathrm{NO}_{6}\left[\mathrm{M}+\mathrm{NH}_{4}\right]^{+}$314.1598, found 314.1596; IR (ATR) $/ \mathrm{cm}^{-1}: 2955,1736,15.12 .1435,1247,1143,1091$.

\section{ASSOCIATED CONTENT}

\section{Supporting Information}

The Supporting Information is available free of charge on the ACS Publications website at DOI: 10.1021/acsomega.8b02047.

Aluminosilicate catalyst characterization methods and characterization data; copies of ${ }^{1} \mathrm{H}$ and ${ }^{13} \mathrm{C}$ NMR spectra for all direct aldol addition compounds (PDF)

\section{AUTHOR INFORMATION}

\section{Corresponding Author}

*E-mail: andrew.graham@southwales.ac.uk.

ORCID

Stuart Hamilton Taylor: 0000-0002-1933-4874

Andrew Edward Graham: 0000-0002-2761-5967

Notes

The authors declare no competing financial interest.

\section{ACKNOWLEDGMENTS}

The authors thank the EPSRC U.K. National Mass Spectrometry Facility at Swansea University for high-resolution mass spectra.

\section{REFERENCES}

(1) Mukherjee, S.; Yang, J. W.; Hoffmann, S.; List, B. Asymmetric enamine chemistry. Chem. Rev. 2007, 107, 5471-5569. 
(2) Perlmutter, P. Conjugated Addition Reaction in Organic Synthesis, 1st ed.; Baldwin, J. E., Ed.; Pergamon Press: Oxford, 1992.

(3) Verkade, J. M. M.; van Hemert, L. J. C.; Quaedflieg, P. J. L. M.; Rutjes, F. P. J. T. Organocatalysed asymmetric Mannich reactions. Chem. Soc. Rev. 2008, 37, 29-41.

(4) Braun, M. Fundamentals and Transition-state Models. Aldol Additions of Group 1 and 2 Enolates. In Modern Aldol Reactions; Mahrwald, R., Ed.; Wiley-VCH: Weinheim, 2004; Vol. 1, pp 1-62.

(5) Machajewski, T. D.; Wong, C.-H. The catalytic asymmetric aldol reaction. Angew. Chem., Int. Ed. 2000, 39, 1352-1374.

(6) Trost, B. M.; Brindle, C. S. The direct catalytic asymmetric aldol reaction. Chem. Soc. Rev. 2010, 39, 1600-1632.

(7) Rodríguez-Llansola, F.; Miravet, J. F.; Escuder, B. A supramolecular hydrogel as a reusable heterogeneous catalyst for the direct aldol reaction. Chem. Commun. 2009, 7303-7305.

(8) Hattori, H. Hererogeneous basic catalysis. Chem. Rev. 1995, 95, 537-558.

(9) Zhu, L.; Liu, X. Q.; Jian, H. L.; Sun, L. B. Metal-organic frameworks for heterogeneous basic catalysis. Chem. Rev. 2017, 117, $8129-8176$

(10) Gauchot, V.; Schmitzer, A. R. Asymmetric aldol reaction catalyzed by the anion of an ionic liquid. J. Org. Chem. 2012, 77, 4917-4923.

(11) Mestres, R. A green look at the aldol reaction. Green Chem. 2004, 6, 583-603.

(12) Ayats, C.; Henseler, H. A.; Pericàs, M. A. A solid-supported organocatalyst for continuous-flow enantioselective aldol reactions. ChemSusChem 2012, 5, 320-325.

(13) Nicolaou, K. C.; Montagnon, T.; Vassilikogiannakis, G.; Mathison, C. J. N. The total synthesis of coleophomones B, C, and D. J. Am. Chem. Soc. 2005, 127, 8872-8888.

(14) Marumoto, S.; Kogen, H.; Naruto, S. Absolute configuration and total synthesis of $(+)$-epolactaene, a neuritogenic agent from penicillium sp. BM 1689-P active in human neuroblastoma cells. J. Org. Chem. 1998, 63, 2068-2069.

(15) Saba, A.; Adovasio, V.; Nardelli, M. Synthesis of enantiomerically pure $\mathrm{C}_{2}$-branched-2-deoxy-heptitols. Tetrahedron: Asymmetry 1992, 3, 1573-1582.

(16) Olivier, J.-H.; Harrowfield, J.; Ziessel, R. 3-Substituted-2,4pentanedionates: ligands for photoactive supramolecular assemblies. Chem. Commun. 2011, 47, 11176-11188.

(17) Umebayashi, N.; Hamashima, Y.; Hashizume, D.; Sodeoka, M. Catalytic enantioselective aldol-type reaction of $\beta$-ketosters with acetals. Angew. Chem., Int. Ed. 2008, 47, 4196-4199.

(18) di Mola, A.; Massa, A. The aldol reactions of active methylene compounds. Curr. Org. Chem. 2012, 16, 2290-2301.

(19) More, V.; Di Mola, A.; Croce, G.; Tedesco, C.; Petronzi, C.; De Caprariis, P.; Peduto, A.; Filosa, R.; Massa, A. Multi-component, regio-selective aldol addition of $\beta$-ketoesters to aldehydes: scope and applications. Org. Biomol. Chem. 2011, 9, 8483-8488.

(20) Buchanan, D. J.; Dixon, D. J.; Hernandez-Juan, F. A. Highly stereoselective intermolecular oxy-Michael addition reaction to $\alpha, \beta$ unsaturated malonate esters. Org. Lett. 2004, 6, 1357-1360.

(21) Antonioletti, R.; Bonadies, F.; Scettri, A. Lewis acid induced $\alpha$ alkoxyalkylation of 1,3-dicarbonyl compounds. J. Org. Chem. 1988, 53, $5540-5542$.

(22) Perkin, W. H. The formation of acids from aldehydes. J. Chem. Soc., Trans. 1886, 49, 317-328.

(23) Klein, J.; Bergmann, E. D. The reaction of acetals with malonic acid and its derivatives. a contribution to the knowledge of the Knoevenagel-Doebner reaction. J. Am. Chem. Soc. 1957, 79, 34523454.

(24) Downey, C. W.; Johnson, M. W.; Tracy, K. J. One-pot enol silane formation-Mukaiyama aldol-type addition to dimethyl acetals mediated by TMSOTf. J. Org. Chem. 2008, 73, 3299-3302.

(25) Li, L.; Ye, X.; Wu, Y.; Gao, L.; Song, Z.; Yin, Z.; Xu, Y. Sakurai reaction of 3,3-bis(silyl) silyl enol ethers with acetals involving selective desilylation of the geminal bis(silane). Concise synthesis of nematocidal oxylipid. Org. Lett. 2013, 15, 1068-1071.
(26) Rodríguez-Gimeno, A.; Cuenca, A. B.; Gil-Tomás, J.; MedioSimón, M.; Olmos, A.; Asensio, G. $\mathrm{FeCl}_{3} \cdot 6 \mathrm{H}_{2} \mathrm{O}$-catalyzed Mukaiyama-aldol type reactions of enolizable aldehydes and acetals. J. Org. Chem. 2014, 79, 8263-8270.

(27) Sagawa, N.; Moriya, H.; Hosokawa, S. Syn selective vinylogous Mukaiyama aldol reaction using $Z, E$-vinylketene $\mathrm{N}, \mathrm{O}$-acetal with acetals. Org. Lett. 2017, 19, 250-253.

(28) Berthet, M.; Songis, O.; Taillier, C.; Dalla, V. Catalytic alkynylation of cyclic acetals and ketals enabled by synergistic gold(I)/trimethylsilyl catalysis. J. Org. Chem. 2017, 82, 9916-9922.

(29) Cosp, A.; Romea, P.; Talavera, P.; Urpi, F.; Vilarrasa, J.; FontBardia, M.; Solans, X. Enantioselective addition of a chiral thiazolidinethione-derived titanium enolate to acetals. Org. Lett. 2001, 3, 615-617.

(30) Kubczyk, T. M.; Williams, S. M.; Kean, J. R.; Davies, T. E.; Taylor, S. H.; Graham, A. E. Nanoporous aluminosilicate catalyzed Friedel-Crafts alkylation reactions of indoles with aldehydes and acetals. Green Chem. 2011, 13, 2320-2325.

(31) Mori, I.; Ishihara, K.; Flippin, L. A.; Nozaki, K.; Yamamoto, H.; Bartlett, P. A.; Heathcock, C. H. On the mechanism of Lewis acid mediated nucleophilic substitution reactions of acetals. J. Org. Chem. 1990, 55, 6107-6115.

(32) Denmark, S. E.; Almstead, N. G. Studies on the mechanism and origin of stereoselective opening of chiral dioxane acetals. J. Am. Chem. Soc. 1991, 113, 8089-8110.

(33) Sammakia, T.; Smith, R. S. Evidence for an oxocarbenium ion intermediate in Lewis acid mediated reactions of acyclic acetals. J. Am. Chem. Soc. 1994, 116, 7915-7916.

(34) Garcia, A.; Sanzone, J. R.; Woerpel, K. A. Participation of alkoxy groups in reactions of acetals: violation of the reactivity/ selectivity principle in a Curtin-Hammett kinetic scenario. Angew. Chem., Int. Ed. 2015, 54, 12087-12090.

(35) Robinson, M. W. C.; Davies, A. M.; Mabbett, I.; Apperley, D. C.; Taylor, S. H.; Graham, A. E. Synthesis and Catalytic Activity of Nanoporous Aluminosilicate Materials. J. Mol. Catal. A: Chem. 2009, $314,10-14$.

(36) Davies, T. E.; Kean, J. R.; Apperley, D. C.; Taylor, S. H.; Graham, A. E. Dehydrative etherification reactions of glycerol with alcohols catalyzed by recyclable nanoprous aluminosilicates: telescoped routes to glyceryl ethers. ACS Sustainable Chem. Eng. 2016, 4, 835-843.

(37) Davies, T. E.; Kean, J. R.; Apperley, D. C.; Taylor, S. H.; Graham, A. E. Nanoporous aluminosilicate-mediated synthesis of ethers by a dehydrative etherification approach. ACS Sustainable Chem. Eng. 2014, 2, 860-866.

(38) Davies, T. E.; Kondrat, S. A.; Nowicka, E.; Kean, J. L.; Harris, C. M.; Socci, J. M.; Apperley, D. C.; Taylor, S. H.; Graham, A. E. Nanoporous Alumino- and Borosilicate-mediated Meinwald Rearrangement of Epoxides. Appl. Catal., A 2015, 493, 17-24.

(39) Yip, L.; Kubczyk, T. M.; Davies, T. E.; Taylor, S. H.; Apperley, D. C.; Graham, A. E. Nanoporous aluminosilicate mediated transacetalisation reactions: application in glycerol valorization. Catal. Sci. Technol. 2012, 2, 2258-2263.

(40) Saravanamurugan, S.; Palanichamy, M.; Hartmann, M.; Murugesan, V. Knoevenagel condensation over $\beta$ and $\mathrm{Y}$ zeolites in liquid phase under solvent free conditions. Appl. Catal., A 2006, 298, $8-15$.

(41) Gaona, A.; Moreno, J. M.; Velty, A.; Díaz, U.; Corma, A. Onepot synthesis of hierarchical porous layered hybrid materials based on aluminosilicate sheets and organic functional pillars. J. Mater. Chem. A 2014, 2, 19360-19375.

(42) Bigi, F.; Chesini, L.; Maggi, R.; Sartori, G. Montmorillonite KSF as an inorganic, water stable, and reusable catalyst for the Knoevenagel synthesis of coumarin-3-carboxylic acids. J. Org. Chem. 1999, 64, 1033-1035

(43) Opanasenko, M.; Dhakshinamoorthy, A.; Shamzhy, M.; Nachtigall, P.; Horáček, M.; Garcia, H.; Čejka, J. Comparison of the catalytic activity of MOFs and zeolites in Knoevenagel condensation. Catal. Sci. Technol. 2013, 3, 500-507. 
(44) Maggi, R.; Bosica, G.; Gherardi, S.; Oro, C.; Sartori, G. ZnNaY zeolite catalysed reaction of $\beta$-dicarbonyl compounds with ethyl cyanoformate under solventless conditions. Green Chem. 2005, 7, $182-184$.

(45) Cheng, X.; Pei, S.; Xue, C.; Cao, K.; Hai, L.; Wu, Y. Reactions of $\beta$-diketone compounds with nitriles catalyzed by Lewis acids: a simple approach to $\beta$-enaminone synthesis. RSC $A d v$. 2014, 4, 63897-63900.

(46) Robinson, M. W. C.; Davies, A. M.; Mabbett, I.; Taylor, S. H.; Graham, A. E. Epoxide Ring-Opening and Meinwald Rearragement Reactions of Epoxides Catalyzed by Mesoporous Aluminosilicates. Org. Biomol. Chem. 2009, 7, 2559-2564.

(47) Robinson, M. W. C.; Graham, A. E. Mesoporous Aluminosilicate Promoted Protection and Deprotection of Carbonyl Compounds. Tetrahedron Lett. 2007, 48, 4727-4731.

(48) Spencer, J. N.; Holmboe, E. S.; Kirshenbaum, M. R.; Firth, D. W.; Pinto, P. B. Solvent effects on the tautomeric equilibrium of 2,4pentanedione. Can. J. Chem. 1982, 60, 1178-1182.

(49) The reaction of 1,3-dicarbonyl compounds with TMOF and TEOF has previously been reported to produce alkoxymethylene derivatives: see (a) Claisen, L. Ber. Dtsch. Chem. Ges. 1893, 26, 27292735. (b) Jones, R. G. The reaction of orthoesters with active methylene compounds. J. Am. Chem. Soc. 1952, 74, 4889-4891.

(50) Kraus, G. A.; Krolski, M. E.; Sy, M. 4-Methoxy-3-penten-2-one. Org. Synth. 1989, 67, 202-203.

(51) Nising, C. F.; Bräse, S. Recent developments in the field of oxaMichael reactions. Chem. Soc. Rev. 2012, 41, 988-999.

(52) Tietze, L. F. Domino reactions in organic synthesis. Chem. Rev. 1996, 96, 115-136.

(53) Faisca Phillips, A. M.; Pombeiro, A. J. L.; Kopylovich, M. N. Recent advances in cascade reactions initated by alcohol oxidation. ChemCatChem 2017, 9, 217-246.

(54) Hayashi, Y. Pot economy and one-pot synthesis. Chem. Sci. 2016, 7, 866-880.

(55) Chaffey, D. R.; Davies, T. E.; Taylor, S. H.; Graham, A. E. Etherification Reactions of Furfuryl Alcohol in the Presence of Orthoesters and Ketals: Application to the Synthesis Furfuryl Ether Bio-Fuels. ACS Sustainable Chem. Eng. 2018, 6, 4996-5002. 